\title{
Monitoring of BALB/C strain mice health, investigation of behavior, hematological parameters under the effect of an electromagnetic field
}

\author{
JUDITA ZYMANTIENE, RASA ZELVYTE, VIDA JUOZAITIENE*, VAIDAS OBERAUSKAS, \\ ALGIS NOREIKA**, NOMEDA JUODZIUKYNIENE***, ALBINA ANIULIENE***
}

\author{
Department of Anatomy and Physiology, Veterinary Faculty, Veterinary Academy; \\ *Department of Animal Breeding, Animal Husbandry Faculty, Veterinary Academy; \\ ** Large Animal Clinic, Veterinary Faculty, Veterinary Academy; \\ ***Department of Veterinary Pathobiology, Veterinary Faculty, Veterinary Academy \\ Lithuanian University of Health Sciences, Mickeviciaus str. 9, LT-44307, Kaunas, Lithuania
}

\section{Zymantiene J., Zelvyte R., Juozaitiene V., Oberauskas V., Noreika A., Juodziukyniene N., Aniuliene A. Monitoring of BALB/C strain mice health, investigation of behavior, hematological parameters under the effect of an electromagnetic field}

\section{Summary}

The aim of this study was to investigate the effect of electromagnetic fields on BALB/c strain mice on their health, body weight, behavior characteristics, hematological parameters and histopathological findings in the brain. The mice of the experimental groups were exposed to electromagnetic waves by using Nokia 230 and Samsung 19300 Galaxy S III mobile phones situated at $2 \mathrm{~cm}$ from the cages. In the present study, it can be concluded that the exposure of mice to mobile phone radiation had an effect on the structure of the brain, behavior and body weight. The waves of mobile phones increased activity characteristics and changed some behavioral categories of mice and also decreased their body weight. Histopathological examination revealed mild edema of neutrophils and degeneration of some neurons and glial cells in the brains of experimental mice. The results of the present study showed that a using mobile phone had an influence on in vivo systems.

Keywords: mobile phone, environment, mouse, behavior, blood, brain

The concept of animal health and human health is one health and integrates the complex relationships between humans, animals, microorganisms, plants, agriculture, wildlife and the environment. Mobile phones (MP) are an integral part of modern telecommunication systems and are widely used worldwide. Mobile communication is now essentially ruling our daily lives through better connectivity and intelligent smartphone services (11). Mobile phones communicate by transmitting radio frequency waves through a network of fixed antennas known as base stations. Such radiations are produced by MP and other household devices such as Wi-Fi, television and radio transmitters, etc. Mobile phones transmit and receive waves of frequencies mainly at $800-1800 \mathrm{MHz}$. Results of animal studies have consistently shown no increase in the cancer risk due to long-term exposure to radiofrequency fields (27). Experimental investigation suggests that radiofrequency fields are not tumor initiators and that if they are related to carcinogenicity, this would be by tumor promotion or by increasing the uptake of carcinogens in cells (3). Epidemiological studies in populations concentrate on a possible causal relationship between MP use and the occurrence of brain tumors, acoustic neuromas, tumors of the salivary glands, and leukemia and lymphomas $(1,4,10,11$, $23,24)$. One of the more vigorously debated issues is whether mobile phone radiation is able to cause DNA damage. Numerous studies have been performed on this subject and while the majority of them shows no effect, there are some studies suggesting that the DNA might be damaged by mobile phone radiation $(9,17)$. On the other hand, RAFIQI et al. (19) obviously indicated that radio frequency radiations directly affect the bio molecules like DNA and produce genetic and genotoxic defects. Mobile radiation has harmful effects on enzyme activity and tissue (1). Moreover, large observational studies suggest that regular and long term use of microwave devices (mobile phone, microwave oven) at the domestic level can have nega- 
tive impact upon biological systems (25) especially on the brain $(18,21,29)$. Studies on humans and rodents have revealed hazards MP radiation associated such as brain tumors, impairment in cognition, hearing, etc. (14). Similar findings were stated by Rafiqi et al. (19) who reported that high-frequency electromagnetic fields of MP alter the resonant stimulus of living organisms and can cause modifications in certain areas of their brain. The disturbance of the nervous system leads to behavioral changes and may serve as an early indicator of disturbances in regulatory functions of many systems. Many controversial studies have been conducted on the effect of the radio waves (RF) emitted from mobile phones on the health of animals and human beings.

The aim of this study was to investigate the effects of electromagnetic fields on BALB/c strain mice health, weight, behavior characteristics, hematological parameters and histopathological findings in the brain.

\section{Material and methods}

Fifteen male and fifteen female BALB/c mice age of four months were used for the experiment. The animals were maintained in transparent polycarbonate cages with a stainless steel grid top in a temperature-controlled room $\left(22 \pm 2^{\circ} \mathrm{C}\right)$, a 12-hrs light/dark cycle (lights on at 7:00 am), with food and water available at libitum. The experiment with animals was in compliance with the rules of the national Animal Ethics Committee and the protocols were designed according to European Parliament Directive 2010/63 EU. The mice were randomly divided into three groups: 2 experimental groups and a control group of 10 animals in each. The animals of the experimental groups I and II have been exposed to radio waves emitted from phones of the Global System for Mobile Communications (GSM) situated at $2 \mathrm{~cm}$ to the polycarbonate cages for a period of 72 hours. group I was exposed to waves frequencies of $900-1800 \mathrm{MHz}$ emitted from a Nokia 23 mobile phone and group II - to waves frequencies 850-1900 MHz emitted from a Samsung 19300 Galaxy S III mobile phone. Group C served as a control group and was not exposed to any of radio wave from mobile phones. The body weight of the mice was set by grams (g) using scales KERN PCB 100-3 (Germany) twice: at the beginning of the experiment, i.e. before the emission of radio waves, and at the end of experiment, i.e. after 72 hours of constant emission of radio waves. Mice activity, motor function and behavioral categories were measured at the end of the experiment according to Rousseau et al. (20). During one hour, from 9:00 a.m. to 10:00 a.m., such characteristics as walking (WA) - the mouse displaces itself, climbing to the top grate of the cage (CL), hanging in the cage (HA), grooming the body, face, front, hind legs (GR), hunch (HU) - the mouse stands on its hind legs while the back is bent, sitting up (SI) - the mouse is immobile, eating (EA), drinking water (DW), pouring bedding $(\mathrm{PB})$ and vocalization (VO) were measured by minutes (min.).

Chain grooming procedures such as elliptical stroke (ES), small unilateral stroke (SUS), large bilateral stroke (LBS) and body licking (BL) were observed during one hour from 08:00 to 09:00 a.m. according to Cromwell et al. (5) three times: the first time at the beginning of the experiment, the second - after 60 hours, and the third time at the end of the experiment at the same time.

After the weight and behavior characteristics were recorded, euthanasia was performed on the mice. Blood samples were collected immediately after euthanasia by cardiac puncture in plastic tubes containing anticoagulant for hematological analysis. The count of red blood cells (RBC), white blood cells (WBC) and hemoglobin content $(\mathrm{Hb})$ were analyzed by the QBC Autoread Plus system (QBC Diagnostics Inc., USA). Total protein (TP) was analyzed by automated the biochemical analyzer SPOTCHEM EZ SP-4430 (Arkray Inc., Japan). The brain of mice was removed from the skull and the size of brain from olfactory lobes to the end of cerebellum was measured by milimeters $(\mathrm{mm})$ using a caliper. For histopathological examination, 4 samples brain were taken from each brain: 2 samples from the cerebellum (left and right sides) and 2 samples from a heamispheres (white and gray matter) and were fixed in formalin $10 \%$. The paraffin blocks were made using „Shandon Pathcentre” (UK) and „TES 99 Medite Medizintechnik” (Germany) equipment. Serial 4- $\mu \mathrm{m}$ sections were prepared with a ,Sakura Accu-Cut SRM" (Japan) microtome from each sample and served for routine H\&E staining.

Statistical analysis was performed using the SPSS program 20.0 for Windows. The experimental data were normally distributed (Kolmogorov-Smirnov test). The results are presented as mean and standard deviation of mean $(\mathrm{M} \pm \mathrm{SD})$ and $95 \%$ confidence interval (CI). The significance of the differences between the evaluated groups was determined with the Student's t-test and $\chi^{2}$ test. The results were considered statistically significant when $\mathrm{P} \leq 0.05$.

\section{Results an discussion}

As in humans, radiofrequencies induce biological effects on biomolecules that include changes in intracellular ionic concentration, cellular proliferation, interferences with the immune system, effects on animal's reproductive capacity, effects on stress hormones in intrauterine development, genotoxic effects, effects on the nervous and circulatory system, and a decline in the number of births $(7,19)$ reported that the increased use of mobile phones has raised the question of possible health effects of such devices, particularly the risk of cancer. It seems unlikely that the low-level radiofrequency (RF) radiation emitted by them would damage DNA directly, but its ability to act as a tumor promoter is less well characterized. Our study clearly demonstrates that mobile phone radiations has a significant effect on mice weight. Data in Table 1 presented weight changes of mice exposed to radio waves emitted from mobile phones. Mice showed a significantly greater decrease in weight, by $12.57 \%$ and $25.34 \%$ in group I and II, respectively, compared to group $\mathrm{C}(\mathrm{P}<0.001)$. In spite of the fact that eating behavior was pronouncedly stronger in mobile phoneexposed animals, their weight was lower compare to that of the control group. A markedly lower influence was observed in animals effected with lower (up to $1800 \mathrm{MHz}$ ) waves frequencies. 
Tab. 1. Difference of mice weight (g) between groups

\begin{tabular}{|l|c|c|c|c|}
\hline $\begin{array}{c}\text { Period of the } \\
\text { experiment }\end{array}$ & Statistic & Group I & Group II & Group C \\
\hline The beginning & $\mathrm{M} \pm$ SD & $24.90 \pm 0.32$ & $24.90 \pm 0.32$ & $24.90 \pm 0.32$ \\
& $95 \% \mathrm{Cl}$ & $24.70-25.09$ & $24.70-25.09$ & $24.70-25.09$ \\
\multirow{3}{*}{ The end } & $\mathrm{M} \pm \mathrm{SD}$ & $21.77 \pm 2.87^{* * *}$ & $18.59 \pm 3.35^{* * *}$ & $24.00 \pm 0.00^{* * *}$ \\
& $95 \% \mathrm{Cl}$ & $19.99-23.54$ & $16.52-20.66$ & $24.00-24.00$ \\
\hline
\end{tabular}

Explanations: $* * *$ means with different superscript letters differ significantly at $\mathrm{P}<0.001 ; \mathrm{M}$ - mean; $\mathrm{SD}$ - standard deviation; $\mathrm{CI}$ - confidence interval

We found that waves of mobile phones increased activity characteristics of mice, such as climbing on the top grate of the cage, hanging in the cage, grooming the body, face, front, hind legs, hunch, eating, drinking water and pouring bedding. Data in Table 2 shows that the effect of the radio waves emitted from mobile phones changed motor functions, activity and some behavior characteristics of mice. In group I walking increased by $2.75 \%$, but there was no changes of this parameter in group II compare to group $\mathrm{C}(\mathrm{P}>0.05)$. Cage climbing of mice significantly increased by $43.07 \%(\mathrm{P}<0.05)$ and $49.23 \%(\mathrm{P}<0.001)$ in groups I and II, respectively, compared to group C. Hunch was manifested often by $1.41 \%$ in group I $(\mathrm{P}>0.05)$

Tab. 2. Measurements of mice activity, motor functions and behavioral characteristics (min.)

\begin{tabular}{|c|c|c|c|c|}
\hline Parameters & Statistic & Group I & Group II & Group C \\
\hline \multirow[t]{2}{*}{ WA } & $M \pm S D$ & $11.20 \pm 1.48$ & $10.30 \pm 0.68$ & $10.90 \pm 0.88$ \\
\hline & $95 \% \mathrm{Cl}$ & $10.14-12.26$ & $9.82-10.78$ & $10.27-11.53$ \\
\hline \multirow[t]{2}{*}{ CL } & $M \pm S D$ & $9.30 \pm 3.77^{\star c}$ & $9.70 \pm 0.48^{* * * c}$ & $6.5 \pm 0.97^{* 1, * * * \|}$ \\
\hline & $95 \% \mathrm{Cl}$ & $6.60-12.00$ & $9.35-10.05$ & $5.8-7.2$ \\
\hline \multirow[t]{2}{*}{ HA } & $M \pm S D$ & $12.30 \pm 1.83^{\star c}$ & $10.90 \pm 1.66$ & $10.40 \pm 0.84^{* 1}$ \\
\hline & $95 \% \mathrm{Cl}$ & $10.99-13.61$ & $9.71-0.53$ & $9.80-11.00$ \\
\hline \multirow[t]{2}{*}{ GR } & $M \pm S D$ & $5.90 \pm 0.88^{* * c}$ & $11.80 \pm 3.12^{* * c}$ & $3.30 \pm 1.42^{* * 1, * * * *}$ \\
\hline & $95 \% \mathrm{Cl}$ & $5.27-6.53$ & $9.57-14.03$ & $2.29-4.31$ \\
\hline \multirow[t]{2}{*}{ HU } & $\mathrm{M} \pm \mathrm{SD}$ & $7.10 \pm 2.13$ & $7.10 \pm 0.99 * * * c$ & $7.00 \pm 0.47^{* * * \|}$ \\
\hline & $95 \% \mathrm{Cl}$ & $5.57-8.63$ & $6.39-7.81$ & $6.66-7.34$ \\
\hline \multirow[t]{2}{*}{ SI } & $\mathrm{M} \pm \mathrm{SD}$ & $4.10 \pm 6.62$ & $3.80 \pm 1.03^{* * \star c}$ & $8.80 \pm 1.03^{* * * \|}$ \\
\hline & $95 \% \mathrm{Cl}$ & $-0.64-8.84$ & $3.06-4.54$ & $8.06-9.54$ \\
\hline \multirow[t]{2}{*}{ EA } & $\mathrm{M} \pm \mathrm{SD}$ & $8.60 \pm 1.96$ & $10.30 \pm 2.63^{\star c}$ & $7.10 \pm 1.45^{* \|}$ \\
\hline & $95 \% \mathrm{Cl}$ & $7.20-10.00$ & $8.42-12.18$ & $6.06-8.14$ \\
\hline \multirow[t]{2}{*}{ DW } & $\mathrm{M} \pm \mathrm{SD}$ & $4.90 \pm 0.88^{\star C}$ & $4.70 \pm 0.68$ & $4.10 \pm 0.57^{\star 1}$ \\
\hline & $95 \% \mathrm{Cl}$ & $4.27-5.53$ & $4.22-5.18$ & $3.69-4.51$ \\
\hline \multirow[t]{2}{*}{ PB } & $\mathrm{M} \pm \mathrm{SD}$ & $5.00 \pm 7.07$ & $5.50 \pm 0.71^{\star * c}$ & $1.00 \pm 2.11^{* * \|}$ \\
\hline & $95 \% \mathrm{Cl}$ & $-0.06-10.06$ & $4.99-6.01$ & $-0.51-2.51$ \\
\hline \multirow[t]{2}{*}{ vo } & $M \pm S D$ & $0.5 \pm 1.58$ & $1.00 \pm 2.11$ & 0 \\
\hline & $95 \% \mathrm{Cl}$ & $-0.63-1.63$ & $-0.51-2.51$ & 0 \\
\hline
\end{tabular}

Explanations: $* * *$ means with different superscript letters differ significantly at $\mathrm{P}<0.001$, ** - at $\mathrm{P}<0.01$, at * $-\mathrm{P}<0.05$; WA - walking; $\mathrm{CL}-$ climbing to the top grate of the cage; HA - hanging in the cage; GR - grooming body, face, hind, front legs; HU - hunch; SI - sitting up; EA - eating; DW - drinking water; $\mathrm{PB}$ - pouring bedding; $\mathrm{VO}$ - vocalization; $\mathrm{M}$ - mean; $\mathrm{SD}$ - standard deviation; $\mathrm{CI}$ - confidence interval and group II $(\mathrm{P}<0.001)$ compare to group $\mathrm{C}$. Sitting up was rarer 2.15-2.32 times in experimental groups compare to the control, but a statistically significant difference was found only between group II and group $\mathrm{C}(\mathrm{P}<0.001)$. Grooming in group I was higher by $78.79 \%$ $(\mathrm{P}<0.01)$ and in group II $(\mathrm{P}<0.001) 3.58$ times compared to group C. Mice of experimental groups ate more actively: group II by $45.07 \%(\mathrm{P}<0.05)$ and group I by $21.13 \%$ $(\mathrm{P}>0.05)$ compared to group $\mathrm{C}$. We noticed a $16.32 \%$ change between drinking measurements in the groups I and $\mathrm{C}(\mathrm{P}<0.05)$. Short vocalization sounds were notice only in experimental groups. This observation is in agreement with studies reporting that electromagnetic radiation can affect biological systems $(2,6,10,18,19,22,25)$ and suggest mobile phones should be kept away from the body (head) by using text messaging, or using a "hands free" devices lowering exposure to radiofrequency fields and, hence, offering better protection. According to Rafiqi et al. (19), exposure of the neural tissue to RFR can cause electrophysiological changes in the nervous system such as efflux of calcium ions from brain tissue. The non systematic and sudden calcium efflux can be manifested in many irregularities of neuronal control, as calcium ion plays an important role in the functions of the nervous system such as the release of neurotransmitters.

Data presented in Table 3 shows grooming characteristics of mice. The elliptical stroke increased in experimental groups compared to the control group during all experimental periods. The small unilateral stroke was highest in group II compared to group I and 2 times higher compared to the control group. We did not notice a difference of the large bilateral stroke between group I and group II, but this parameter was higher compared to the control group. Body licking in group I was 3 times and in group II 4 times higher compared to the control group during all experimental periods.

Data in Table 4 reveals proportions of mice grooming periods. The grooming periods of mice changed because of the action of radio waves from mobile phones. ES increased by $20.00 \%$ in group I $(\mathrm{P}<0.05)$ and by $40.00 \%$ in group II $(\mathrm{P}<0.001)$ compared to group C. SUS increased by $10.00 \%$ in group I and by $30.00 \%(\mathrm{P}<0.001)$ in group II $(\mathrm{P}<0.05)$ compared to group C. LBS increased by $30.00 \%$ in group I $(\mathrm{P}<0.001)$ and group II $(\mathrm{P}<0.001)$ compared to group $\mathrm{C}$ and $\mathrm{BL}$ increased by $30.00 \%$ in group I $(\mathrm{P}<0.01)$ and by $50.00 \%$ in group II $(\mathrm{P}<0.001)$ compared to group $\mathrm{C}$. 
Tab. 3. Grooming characteristics of mice during one hour

\begin{tabular}{|c|c|c|c|c|}
\hline Parameters & $\begin{array}{c}\text { Period of the } \\
\text { experiment }\end{array}$ & Group I, unit/\% & Group II, unit/\% & Group C, unit/\% \\
\hline \multirow[t]{4}{*}{ ES } & The beginning & $0 / 0.00$ & $0 / 0.00$ & $1 / 10.00$ \\
\hline & After $60 \mathrm{~h}$ & $1 / 10.00$ & $3 / 30.00$ & $1 / 10.00$ \\
\hline & The end & $5 / 50.00$ & $5 / 50.00$ & $2 / 20.00$ \\
\hline & Total, \% & 60.00 & 80.00 & 30.00 \\
\hline \multirow[t]{4}{*}{ SUS } & The beginning & $2 / 20.00$ & $2 / 20.00$ & $0 / 0.00$ \\
\hline & After $60 \mathrm{~h}$ & $4 / 40.00$ & $5 / 50.00$ & $2 / 20.00$ \\
\hline & The end & $4 / 40.00$ & $5 / 50.00$ & $3 / 30.00$ \\
\hline & Total, \% & 80.00 & 100.00 & 50.00 \\
\hline \multirow[t]{4}{*}{ LBS } & The beginning & $3 / 30.00$ & $3 / 30.00$ & $2 / 20.00$ \\
\hline & After $60 \mathrm{~h}$ & $5 / 50.00$ & $6 / 60.00$ & $4 / 40.00$ \\
\hline & The end & $5 / 50.00$ & $4 / 40.00$ & $2 / 20.00$ \\
\hline & Total, \% & 100.00 & 100.00 & 60.00 \\
\hline \multirow[t]{4}{*}{ BL } & The beginning & $0 / 0.00$ & $2 / 20.00$ & $1 / 10.00$ \\
\hline & After $60 \mathrm{~h}$ & $2 / 20.00$ & $4 / 40.00$ & $1 / 10.00$ \\
\hline & The end & $4 / 40.00$ & $4 / 40.00$ & $1 / 10.00$ \\
\hline & Total, \% & 60.00 & 80.00 & 20.00 \\
\hline
\end{tabular}

Explanations: ES - elliptical stroke; SUS - small unilateral stroke; LBS - large bilateral stroke; BL - body licking

Tab. 4. Proportions of mice grooming periods between groups

\begin{tabular}{|c|c|c|c|c|c|c|}
\hline Parameters & $\begin{array}{l}\text { Period of the } \\
\text { experiment }\end{array}$ & Group & Difference, \% & $95 \% \mathrm{Cl}$ & $\chi^{2}$ & $\mathbf{P}$ \\
\hline \multirow[t]{4}{*}{ ES } & \multirow[t]{2}{*}{ The beginning } & $\mathrm{I} / \mathrm{C}$ & 10 & $-7.6535-30.1034$ & 2.053 & 0.1519 \\
\hline & & II/C & 0 & $-16.1125-16.1125$ & - & - \\
\hline & \multirow[t]{2}{*}{ The end } & $\mathrm{I} / \mathrm{C}$ & 30 & $-0.5772-53.8135$ & 3.545 & 0.0597 \\
\hline & & II/C & 50 & $19.2408-69.5243$ & 9.848 & 0.0017 \\
\hline \multirow[t]{4}{*}{ SUS } & \multirow[t]{2}{*}{ The beginning } & $\mathrm{I} / \mathrm{C}$ & 20 & $-0.0509-41.6017$ & 4.333 & 0.0374 \\
\hline & & II/C & 20 & $-0.0509-41.6017$ & 4.333 & 0.0374 \\
\hline & \multirow[t]{2}{*}{ The end } & $\mathrm{I} / \mathrm{C}$ & 30 & $0.5136-53.3503$ & 3.857 & 0.0495 \\
\hline & & $\mathrm{II} / \mathrm{C}$ & 50 & $24.2624-70.0702$ & 13.000 & 0.0003 \\
\hline \multirow[t]{4}{*}{ LBS } & \multirow[t]{2}{*}{ The beginning } & $\mathrm{I} / \mathrm{C}$ & 10 & $-16.5595-34.9383$ & 0.520 & 0.4708 \\
\hline & & II/C & 10 & $-16.5595-34.9383$ & 0.520 & 0.4708 \\
\hline & \multirow[t]{2}{*}{ The end } & $\mathrm{I} / \mathrm{C}$ & 40 & $15.7529-61.3418$ & 9.750 & 0.0018 \\
\hline & & II/C & 40 & $15.7529-61.3418$ & 9.750 & 0.0018 \\
\hline \multirow[t]{4}{*}{ BL } & \multirow[t]{2}{*}{ The beginning } & $\mathrm{I} / \mathrm{C}$ & 10 & $-7.6535-30.1034$ & 2.053 & 0.1519 \\
\hline & & II/C & 10 & $-13.3789-32.7743$ & 0.765 & 0.3819 \\
\hline & \multirow[t]{2}{*}{ The end } & $\mathrm{I} / \mathrm{C}$ & 40 & $9.6337-61.6965$ & 6.500 & 0.0108 \\
\hline & & $\mathrm{II} / \mathrm{C}$ & 60 & $29.4505-76.8776$ & 14.040 & 0.0002 \\
\hline
\end{tabular}

Explanations: ES - elliptical stroke; SUS - small unilateral stroke; LBS - large bilateral stroke; BL - body licking; CI - confidence interval

Tab. 5. The size of the brain from the olfactory lobes to the end of cerebellum ( $\mathrm{mm})$

\begin{tabular}{|l|c|c|c|}
\hline \multicolumn{1}{|c|}{ Statistic } & Group I & Group II & Group C \\
\hline $\mathrm{M} \pm \mathrm{SD}$ & $16.25 \pm 2.12$ & $16.63 \pm 2.07$ & $16.43 \pm 2.03$ \\
\hline $95 \% \mathrm{CI}$ & $14.78-17.72$ & $15.19-18.06$ & $15.44-17.43$ \\
\hline
\end{tabular}

Rafiqi et al. (19) reported that an increased exposure to radio frequency can have thermal effects on health mainly due to holding mobile phones close to the body for a long period of time. Disturbance of the nervous system leads to behavioral changes and may serve as an early indicator of disturbances in the regulatory functions of many systems. Narayanan et al. (13) indicated that mobile phone radiation could affect the emotionality of rats without affecting their general locomotion. But Júnior et al. (8) have suggested that radiofrequency electromagnetic radiation from a GSM cell phone may lead to stressful behavioral patterns. Similarly, Saikhedkar et al. (21) reported that there are significant differences in behavior, i.e. more anxiety and poor learning, between control animals and rats of the test group affected by $900 \mathrm{MHz}$ radiofrequency radiation of mobile phone.

We estimate that brain parameters from olfactory lobes to the end of cerebellum after the impact of the mobile phone has changed $1.15 \%(\mathrm{P}>0.05)$. Data in Table 5 shows the brain size of mice from olfactory lobes to the end of cerebellum. In group I this parameter was lower by $1.10 \%$, in group II was higher by $1.20 \%(\mathrm{P}>0.05)$ compared to the control group. These changes may be in association with mild edema of neutrophil and degeneration in the brain. In our study edema of the brain neutrophil may be arise in association with changes in the circulatory system induced by hyperthermia.

Evaluation of blood parameters is one of the most important methods by which we can determine the health status of experimental animals. We did not determine any significance changes of RBC, WBC count, $\mathrm{Hb}$ content and TP between groups (Tab. 6). Singh et al. (25) reported that magnetic fields resulted in a decrease of RBC membrane elasticity and permeability and changes the structure of $\mathrm{Hb}$. In the present study, we did not establish statistically significant differences between hematological parameters of mice. Our observations confirm the findings obtained by Singh et al. (25) that only continuous exposure to extremely low frequency electromagnetic field may affect the blood parameters of mice. 
Tab. 6. Hematological parameters of mice

\begin{tabular}{|l|c|c|c|c|c|}
\hline Groups & Statistic & $\mathrm{RBC}, \times 10^{12} / \mathrm{L}$ & $\mathrm{WBC}, \times 10^{9} / \mathrm{L}$ & $\mathrm{Hb}, \mathrm{g} / \mathrm{L}$ & $\mathrm{TP}, \mathrm{g} / \mathrm{L}$ \\
\hline $\mathrm{I}$ & $\mathrm{M} \pm \mathrm{SD}$ & $5.2 \pm 0.13$ & $9.03 \pm 1.03$ & $90.63 \pm 3.07$ & $41.68 \pm 0.15$ \\
& $95 \% \mathrm{Cl}$ & $5.1-5.3$ & $8.29-9.76$ & $88.06-93.19$ & $41.55-41.80$ \\
II & $\mathrm{M} \pm \mathrm{SD}$ & $5.12 \pm 0.65$ & $8.78 \pm 0.79$ & $90.5 \pm 2.56$ & $41.69 \pm 0.14$ \\
& $95 \% \mathrm{Cl}$ & $4.62-5.62$ & $8.21-9.34$ & $88.36-92.64$ & $41.57-41.81$ \\
C & $\mathrm{M} \pm \mathrm{SD}$ & $5.26 \pm 0.36$ & $8.96 \pm 0.65$ & $90.25 \pm 2.12$ & $41.65 \pm 0.15$ \\
& $95 \% \mathrm{Cl}$ & $4.99-5.54$ & $8.50-9.43$ & $88.48-92.02$ & $41.53-41.77$ \\
\hline
\end{tabular}

Explanations: RBC - red blood cells; WBC - white blood cells; $\mathrm{Hb}$ - haemoglobin; TP - total protein; $\mathrm{M}$ - mean; $\mathrm{SD}$ - standard deviation; $\mathrm{CI}$ - confidence interval

Histopathological examination of the brains of experimental groups did not show significant changes. In the great hemisphere of the mice of group I there were mild edema of neurophil, vacuolization of cytoplasma in some neurons and glial cells (Fig. 1). In the cerebellum there were hyperemia and mild edema of the molecular layer. Purkinje cells were gaily colored and shrunk

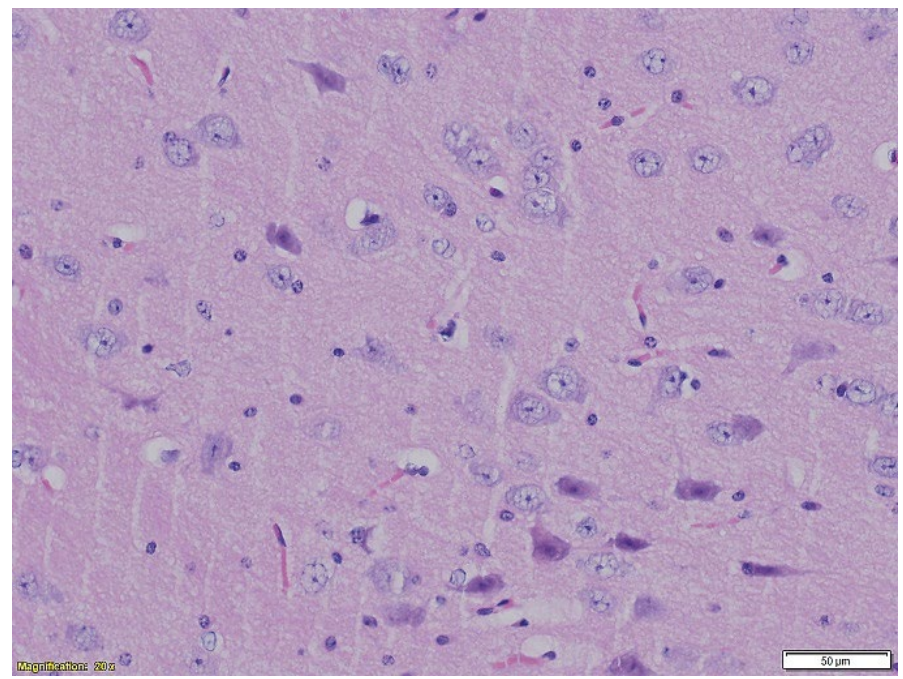

Fig. 1. Mild edema of neuropil, vacuolization of some neurons, and glial cells in great hemispheres, shrinkage of some pyramidal neurons of mice from group I. HE, $\times 200$

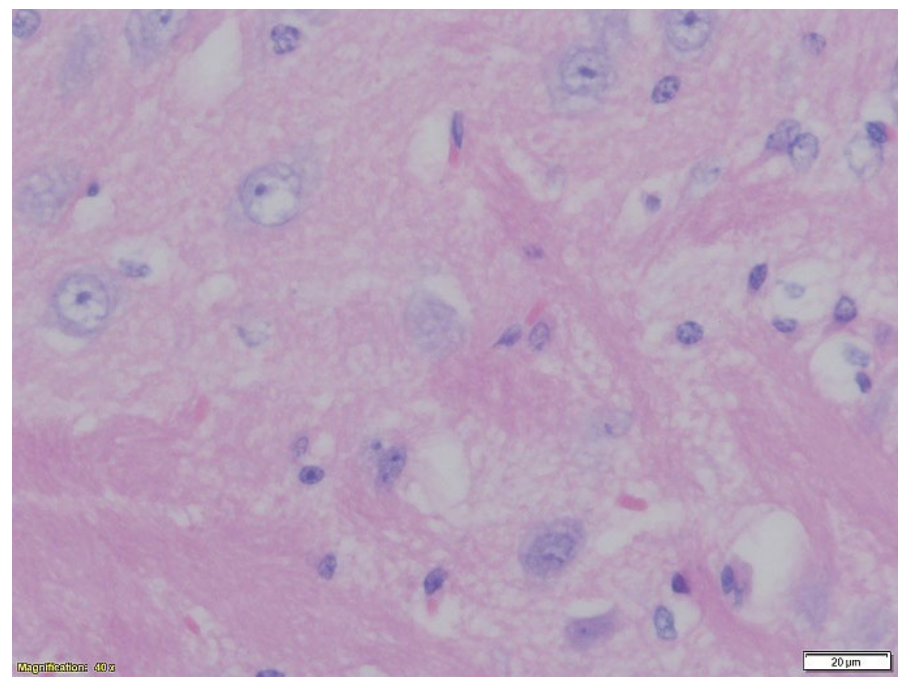

Fig. 3. More intense edema of neuropil, vacuolization of glial cells and shrunk pyramidal cells of mice from group II. HE, $\times 200$ due to degeneration changes. (Fig. 2). In group II the changes were similar, but more widespread (Fig. 3, 4, 5). Panagopoulos et al. (16) found that microwave radiations used in modern mobile telecommunications can damage DNA and induce cell death or heritable mutations which may in turn result in reproduction decreases, degenerative diseases or cancer. The findings of Saikhedkar et al. (21) showed a widespread neurodegeneration from radio waves. In our study we found neurodegenerative changes in the brains of mice exposed to radio frequency waves. The reason for these changes may be in association with oxidative stress or hyperthermia due to the effect of electromagnetic waves (26). Yakymenko et al. (28) indicated that a broad spectrum of health disorders and diseases could be caused by the substantial overproduction of reactive oxygen species (ROS) in living cells under radio frequency radiation

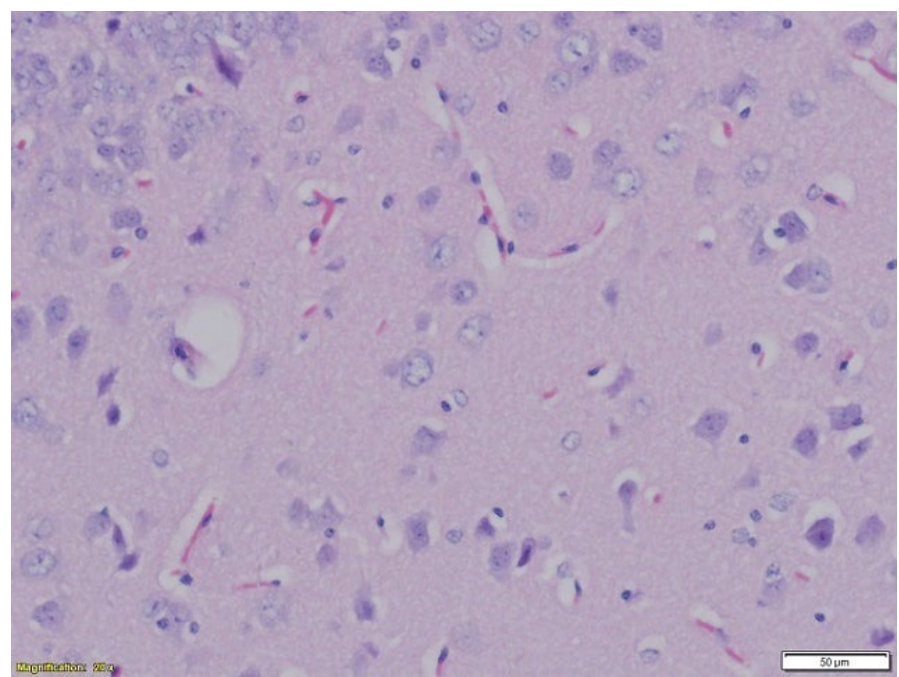

Fig. 2. Shrinkage (dark, smaller) of some Purkinje cells and mild edema in the cerebellum of mice from group $\mathrm{I}, \mathrm{HE}, \times 200$

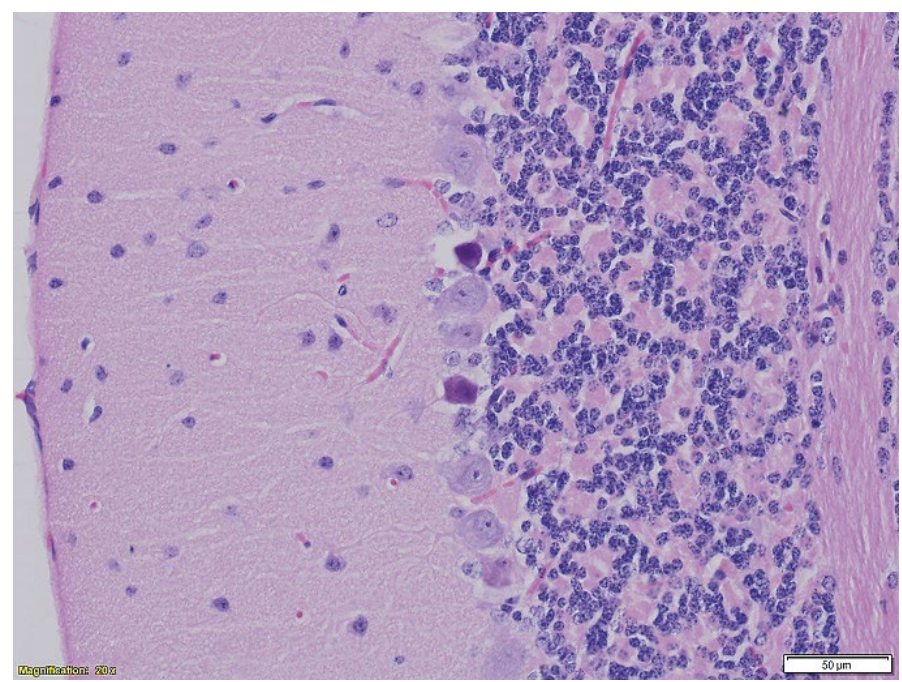

Fig. 4. Vacuolization of neurons and glial cells, edema of neuropil of mice from group II, HE, $\times 400$ 


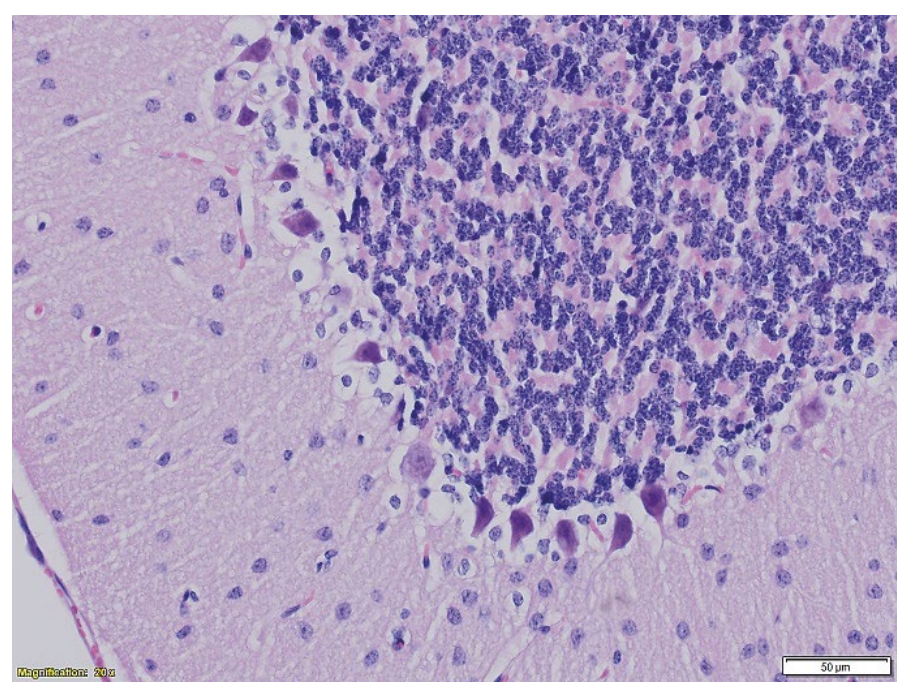

Fig. 5. Shrinkage (dark, smaller) of many Purkinje cells and severe edema in the cerebellum of mice from group II, HE, $\times 200$

exposure. Increasing the production of ROS due to the exhaustion of enzymatic and non-fermentative substances antioxidants and elevated lipid peroxidation indicate a significant neurodegeneration in selective areas of the rat brain and cerebral cortex. Narayanan et al. (12) reported that oxidant stress and antioxidant defense developed in brain regions of rats exposed to $900 \mathrm{MHz}$ radiation. In our case gliocytes were commonly degenerated. Moreover, Panagopoulos et al. (15) noted that as the scientific database regarding the biological effects of electromagnetic fields emitted by modern telecommunications continues to grow, it is important for experimental study designs to become more rigorous and provide a more informed basis for interpretation.

In the present study, it can be concluded that exposure of BALB/C strain mice to mobile phone radiation had an effect on the structure of the brain, behavior and body weight. Histopathological findings revealed mild edema of neutrophil and the degeneration of some neurons and glial cells in the brain of experimental mice. The frequency waves of mobile phones increased activity characteristics and changed some behavioral categories of mice also decreased their body weight. The results of the present study showed that using a mobile phone had an influence on in vivo systems.

\section{References}

1.Aberumand M., Mansouri E., Pourmotahari F., Mirlohi M., Abdoli Z.: Biochemical and histological effects of mobile phone radiation on enzymes and tissues of mice. Res. J. Pharm. Biol. Chem. Sci. 2016, 7, 1962-1971.

2. Aziz A., EL-Khozondar H. J., Shabat M., Elwasife K., Mohamed-Osman A.: Effect of electromagnetic field on body weight and blood indices in albino rats and the therapeutic action of vitamin C or E: Rom. J. Biophys. 2010, 20, 235-244

3. Blettner M., Berg G.: Are mobile phones harmful? Acta Oncologica 2000, 39, 927-930.

4. Carlberg M., Hanssonmild K., Hardell L.: Use of mobile phones and cordless phones is associated with increased risk for glioma and acoustic neuroma. Pathophysiology 2013, 20, 85-110.

5. Cromwell H. C., Berridge K. C., Drago J., Levine M. S.: Action sequencing is impaired in D1A-deficient mutant mice. Europ. J. Neurosc. 1998, 10, 2426-2432.
6. Hardell L., Carlberg M.: Mobile phones, cordless phones and the risk for brain tumours. Internat. J. Oncol. 2009, 35, 5-17.

7. Heikkinen P., Kosma V. M., Hongisto T., Huuskonen H., Hyysalo P., Komulainen $H$.: Effects of mobile phone radiation on X-ray-induced tumorigenesis in mice. Radiation Res. 2001, 156, 775-785.

8. Júnior L. C., Guimarães E. S., Musso C. M., Stabler C. T., Garcia R. M. Mourão-Júnior C. A., Andreazzi A. E.: Behavior and memory evaluation of Wistar rats exposed to $1.8 \mathrm{GHz}$ radiofrequency electromagnetic radiation. Neurolog. Res. 2014, 36, 800-803.

9. Leszczynski D., Xu Z.: Mobile phone radiation health risk controversy: the reliability and sufficiency of science behind the safety standards. Health Res. Policy Systems 2010, 8, doi:10.1186/1478-4505-8-2.

10. Lin I. M., Peper E.: Psychophysiological patterns during cell phone text messaging: a preliminary study. Appl. Psychophysiol. Biofeed. 2009, 34, 53-57.

11. Meena J. K., Verma A., Kohli C., Ingle G. K.: Mobile phone use and possible cancer risk: Current perspectives in India. Indian J. Occupat. Environ. Medicine 2016, 20, 5-9.

12.Narayanan S. N., Kumar R. S., Paval J., Kedage V., Bhat M. S., Nayak S., Bhat P. G.: Analysis of emotionality and locomotion in radio-frequency electromagnetic radiation exposed rats. Off. J. Ital. Neurolog. Soc. Ital. Soc. Clin. Neurophysiol. 2013, 34, 1117-1124.

13. Narayanan S. N., Kumar R. S., Kedage V., Nalini K., Nayak S., Bhat P. G.: Evaluation of oxidant stress and antioxidant defense in discrete brain regions of rats exposed to $900 \mathrm{MHz}$ radiation. Bratislava Med. J. 2014, 115, 260-266.

14. Nirwane A., Sridhar V., Majumdar A.: Neurobehavioural changes and brain oxidative stress induced by acute exposure to GSM 900 mobile phone radiations in zebrafish (Danio rerio). Toxicolog. Res. 2016, 32, 123-132.

15. Panagopoulos D. J., Johansson O., Carlo G. L.: Real versus simulated mobile phone exposures in experimental studies. BioMed Res. Internat. 2015, 1-8, doi: $10.1155 / 2015 / 607053$

16. Panagopoulos D. J., Karabarbounis A., Lioliousis C. E.: Alternating magnetic field decreases reproduction by DNA damage induction. Cell Biochem. Biophys. 2013, 67, 703-716.

17. Phillips J. L., Singh N. P., Lai H.: Electromagnetic fields and DNA damage. Pathophysiology 2009, 16, 79-88.

18. Prasad M., Kathuria P., Nair P., Kumar A., Prasad K.: Mobile phone use and risk of brain tumours: a systematic review of association between study quality, source of funding, and research outcomes. Neurolog. Sci. 2017, 38, 797-810.

19. Rafiqi S., Saroj I., Kumar S., Chaudhary R., Farooq U. B., Kirthika P.: Mobile phone radiations and its impact on birds, animals and human beings. Internat. J. Anim. Vet. Sci. 2016, 3, 25-28.

20. Rousseau J. B., Van Lochem P. B., Gispen W. H., Spruijt B. M.: Classification of rat behavior with an image-processing method and a neural network. Behav. Res. Meth. Instruments Computers 2000, 32, 63-71.

21. Saikhedkar N., Bhatnagar M., Jain A., Sukhwal P., Sharma C., Jaiswal N.: Effects of mobile phone radiation ( $900 \mathrm{MHz}$ radiofrequency) on structure and functions of rat brain. Neurolog. Res. 2014, 36, 1072-1079.

22. Sato Y., Akiba S., Kubo O., Yamaguchi N.: A case-case study of mobile phone use and acoustic neuroma risk in Japan. Bioelectromagnetics 2011, 32, 85-93.

23.Schüz J., Böhler E., Berg G., Schlehofer B., Hettinger I., Schlaefer K., Wahrendorf J., Kunna-Grass K., Blettner M.: Cellular phone, cordless phones and the risk of glioma and meningioma. Am. J. Epidemiol. 2006, 163, 512-520.

24. Shahin S., Mishra V., Singh S. P., Chaturvedi C. M.: 2.45-GHz microwave irradiation adversely affects reproductive function in male mouse, Mus musculus by inducing oxidative and nitrosative stress. Free Radical Res. 2014, 48, 511-525.

25.Singh S., Brocker C., Koppaka V., Chen Y., Jackson B. C., Matsumoto A., Thompson D. C., Vasiliou V:: Aldehyde dehydrogenases in cellular responses to oxidative/electrophilic stress. Free Radical Biol. Med. 2013, 56, 89-101.

26. Stam R.: Electromagnetic fields and the blood-brain barrier. Brain Res. Rev. 2010, 65, 80-97.

27. Volkow N. D., Tomasi D., Wang G. J., Vaska P., Fowler J. S., Telang F.: Effects of cell phone radiofrequency signal exposure on brain glucose metabolism. J. Am. Med. Ass. 2011, 305, 808-813.

28. Yakymenko I., Sidorik E., Henshel D., Kyrylenko S.: Low intensity radiofrequency radiation: a new oxidant for living cells. Oxidants Antioxidants Med. Sci. 2014, 3, 1-3.

29. Yang M., Guo W. W., Yang C. S., Tang J. Q., Huang Q., Feng S. X., Jiang A. J., $X u$ X. F., Jiang G., Elder J. B.: Mobile phone use and glioma risk: A systematic review and meta-analysis. PLoS one. 2017, 12, e175136.

Corresponding author: Prof. Dr. Judita Zymantiene, Lithuanian University of Health Sciences, Mickeviciaus str. 9, Veterinary Academy, LT-44307, Kaunas, Lithuania; e-mail: judita.zymantiene@Ismuni.It 